\title{
Shifting between counterproductive work behavior and organizational citizenship behavior: The effects of workplace support and engagement
}

\author{
$\mathrm{Hu}$, Yueh-Luen \\ Department of Education, National Chengchi University, Taiwan (joyhu@nccu.edu.tw) \\ Hung, Chao-Hsiang \\ Department of Education, National Chengchi University, Taiwan (aka0518@gmail.com)
}

Ching, Gregory S. $\bowtie$

Graduate Institute of Educational Leadership and Development, Fu Jen Catholic University, Taiwan

(gregory_ching@yahoo.com; 094478@mail.fju.edu.tw)

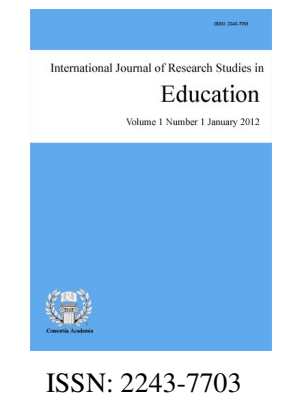

Online ISSN: 2243-7711

OPEN ACCESS

\section{Abstract}

Organizational behavior studies have noted the positive effects of perceived support and employees' engagement towards the overall institutional performance. However, recent studies suggest that both the positive organizational citizenship behavior (OCB) and the negative counterproductive work behavior (CWB) are also highly affected by job engagement. In the academic setting, maintaining a well-balanced work place is highly important. Recent studies in Taiwan have noted the moderate occurrence of CWBs within the academic setting; as students are greatly influenced by their teachers, it is imperative that CWBs be kept to a minimum. In light of the above-mentioned issues, the current study shall present the findings in determining the inter-relationships between perceived support (PS), job engagement (JE), OCB, and CWB Taiwan (CWB-T) model. Participants are 1,074 teachers from Taiwan. Structured equation modelling (SEM) was used to analyze the proposed mediation model. Instrument used are $\mathrm{Hu}$, Hung, and Ching's (2015) CWB Taiwan scale, Eisenberger, Stinglhamber, Vandenberghe, Sucharski, and Rhoades' (2002) perceived support, Saks' (2006) job engagement, and Lee and Allen's (2002) organizational citizenship behavior. Lastly, findings suggest that job engagement seem to provide a negative effect on CWB-T, while at the same time provide a positive effect on OCB. In sum, appropriate organizational support is much needed in order to enhance workplace engagement. It is hoped that by pin-pointing the various determinants of CWBs, a clear understanding of the inter-relationships among the factors can be establish.

Keywords: work attitude; teacher; deviant behavior; support; counterproductive work behavior; organizational citizenship behavior; job engagement; latent mediator 


\section{Shifting between counterproductive work behavior and organizational citizenship behavior: The effects of workplace support and engagement}

\section{Introduction}

Within workplace research, many have noted the significant relationship that exists between performance and the state of organizational citizenship behavior (OCB) (Podsakoff \& MacKenzie, 1997; Podsakoff, MacKenzie, Paine, \& Bachrach, 2000). Although their studies are accomplished more than a decade ago, in reality this phenomenon still holds true, wherein OCB is quite related to an individuals' performance (Zhong, Wayne, \& Liden, 2015). More important is that within their study, they also noted the important role of workplace support and job engagement placed on an individuals' performance. It is said that in due time, effective workplace engagement does not only improved performance, but also creates loyalty (Salanova, Agut, \& Peiró, 2005). While, the perceived supports including both from an individuals' superior and from the organization itself, are said to be beneficial in creating a healthy work environment (Kossek, Pichler, Bodner, \& Hammer, 2011).

Within another spectrum, besides OCB, the notion that counterproductive work behavior (CWB) exists in all levels of the workplace is also gaining grounds in terms of its antecedents and perceived negative effects towards institutions and/or organizations (Martinko, Gundlach, \& Douglas, 2002). More important, are the complex relationship that exists between OCB and CWB. Many have delved on either the distinct (Sackett, Berry, Wiemann, \& Laczo, 2006) or the relative nature of the two concepts (Dalal, 2005; Spector \& Fox, 2010), in fact, researchers have shown the existence of some apparent parallel concepts between OCB and CWB (Miles, Borman, Spector, \& Fox, 2002). However, with the diverse conceptions of CWB, one fact still remains, which is the deviant workplace behaviors tend to lowers the overall institutional performance and efficiency (Robbins, Ford, \& Tetrick, 2012).

Inside the academic setting, OCB and CWB are simultaneously occurring (Britt \& Jex, 2015; T. H. Stone \& Jawahar, 2015). Studies have noted the positive contributions of OCB in the academic workplace, which is actually quite promising (Bogler \& Somech, 2004; Christ, Van Dick, Wagner, \& Stellmacher, 2003; Somech \& Bogler, 2002). This actually holds true with regards to Taiwan teachers. Recent students have noted that the perceived administrative practices within the academic workplace is quite relevant to the levels of teachers' OCB (Chang, Nguyen, Cheng, Kuo, \& Lee, 2016; Nguyen, Chang, Rowley, \& Japutra, 2016). Similarly, with regards to $\mathrm{CWB}$, recent findings have noted the perceived moderate occurrence of various deviant behaviors within Taiwan academic workplace (Ching, Tsay, Hu, \& Hung, 2016; Y.-L. Hu, Hung, \& Ching, 2015). With these having said, it is noted that in order to improve the academic workplace in Taiwan, it would be advisable to further understand the inner workings of both OCB and CWB. More important, is the inter-relationship of work engagement and perceived support towards the occurrences of OCB and CWB.

\section{Conceptual review}

\subsection{Organizational citizenship behavior}

Within the seminal literature, Organ (1988) noted the complex nature of OCB that has an aggregate positive impact on institutional effectiveness. In general, OCB can be described as a voluntary act in helping others or altruism (Smith, Organ, \& Near, 1983). Organ and Ryan (1995) further added that OCB is highly related to an individuals' job satisfaction, while also holding true for other workplace attitudinal measures, such as: fairness, commitment, and support. Stressing on the part of organizational justice, as noted by Moorman, Niehoff, and Organ (1993) that most of the relationship between OCB and satisfaction are actually contributed the sense of 
equality or perceived justice within the organization. While, referring back to a study by $\mathrm{Hu}$, Hung, and Ching (2016) suggesting that equity plays an important part in creating a healthy workplace. With these relationship in placed, it would seem that OCB is generated through having a healthy workplace. More important is that within this healthy workplace, the practice of fairness or equality and support are clearly felt by its constituents.

Later on, Organ (1997) expressed that OCB is not simply the concepts of performing beyond what is expected of an individual. OCB can be considered to be more contextual in nature (Borman \& Motowidlo, 1997). Contextual in a sense that performance is directed towards the organization/institution (Borman \& Motowidlo, 1993). This also includes the uplifting of the social and psychological aspects of the organization (Borman \& Motowidlo, 1997), while can be refined to include interpersonal facilitation and job dedication (Van Scotter \& Motowidlo, 1996). An important notion is that this contextual performance seems to varies from individual to individual (Motowildo, Borman, \& Schmit, 1997) and could be highly related to a person's personality (Hogan, Rybicki, \& Borman, 1998). Lastly, as with the aggregating nature of OCB construct, positive workplace performance such as organizational effectiveness, individual motivation, job satisfaction, and commitment are highly attributed. Hence, OCB is encouraged.

\subsection{Counterproductive work behavior}

As the notion of CWB exists in all workplace, various studies regarding the variability of its concepts have been published. In simple terms, day to day CWBs are various negative workplace behaviors such as minor conflicts and bullying (Ayoko, Callan, \& Härtel, 2003), coming to work late and/or leaving early, non-work related internet use, and talking behind somebody's back or spreading rumors (Y.-L. Hu et al., 2015). More specifically, these CWBs are considered intentional behaviors that are harmful to the organization (or institution) and/or to the people within that organization (Dalal, 2005; Gruys \& Sackett, 2003; Sackett, 2002). Besides the common day to day CWBs, some other more serious deviant behaviors are workplace related aggression towards coworkers (Hershcovis et al., 2007), workplace theft, fraud, and even embezzlement (Bowling \& Gruys, 2010; Marcus \& Schuler, 2004; Robinson \& Bennett, 1995), just to name a few. With these day to day CWB occurrences, an overall damaging effect towards the organizational well-being is taking place (Klotz \& Buckley, 2013). In essence, these negative behaviors are making its toll within the workplace.

Researches have shown the multi-dimensionality of CWBs. Many have classified CWB in terms of their severity from minor to severe and in terms of their impact either towards a personal or organizational level (Y.-L. Hu et al., 2015). Many have also used the classification method by Robinson and Bennett (1995), wherein they grouped CWBs into four distinct clusters, namely: production deviance, property deviance, political deviance, and personal aggression (p. 565). However, this was later reclassified into five simpler categories, such as: abuse towards others, production deviance, sabotage, theft, and withdrawal (Spector et al., 2006). However, Bowling and Gruys (2010) organized the CWBs within a comparative perspective, in terms of legal versus illegal activities, hostile versus instrumental aggression, and task-related versus non-task related, noting the complexity of CWBs.

Within the academic setting, as previous studies have shown that CWBs are also occurring (Ching et al., 2016; Y.-L. Hu et al., 2015, 2016). Citing previous researches, some have suggested that even in the unlikely place of occurring negative behaviors in teachers such as within the school, it can be noted that teaching can be a stressful occupation, hence, CWBs seems to be associated with work related tension and anxiety (Fox \& Stallworth, 2010). In addition, Chughtai and Zafar (2006) noted that organizational factors such as: job satisfaction and perceived justice as some of the mediating factors for organizational commitment, which is considered as positive behaviors. In some cases, the actual enforcement of workplace monitoring and sanctioning are seen as preemptive measures for CWB occurrences (Y.-L. Hu et al., 2016). In sum, promoting a positive healthy workplace, such as with the like of enhancing organizational commitment is seen as helpful in minimizing CWBs. 
As with the varied aspects of CWBs, this also holds true with the complexity of its predictors. An early study by Martinko (2002) and his colleagues argues that CWBs are caused either by situational issues or triggered by some personal concerns. Conforming to their notion, studies by Moretti (1986) and Dobbins, Pence, Orban, and Sgro (1983) both suggests that there are instances wherein CWBs are gender specific, such as with male employees are more prone to violence, alcohol (or substance) abuse, or theft, while female workers might have a tendency to undergo favoritism and participate in office politics. In addition, the age of the employee also seems to matter, for instance, younger individuals are more likely to exhibit CWB tendencies as compared to the more senior employees (Hershcovis et al., 2007; Penney \& Spector, 2005). Furthermore, individual personalities also matters greatly (Hogan et al., 1998; Phillips, Meek, \& Vendemia, 2011; Spector, 2011). For instance, the personality conscientiousness seems to counter the urged to commit CWBs (Berry, Ones, \& Sackett, 2007). Lastly, as with the preferred antecedents of CWBs are situational, so as interventions can be implemented, whereas with personal triggers (such as gender and age) of deviant behaviors are beyond the control of an organization, hence, additional clarification on the various workplace settings are needed.

\subsection{Workplace engagement}

The concept of engagement in the workplace is fast becoming an important issue. Within the literatures, two parallel concepts have actually emerged, namely: work engagement and job engagement. Work engagement is a more generalized concept that described the positive motivational state of work-related well-being (Bakker, Schaufeli, Leiter, \& Taris, 2008, pp. 187-188). This motivational state can also be described as being full of energy and enthusiasm (Bakker \& Demerouti, 2008). More important, is that having a healthy engaged career would tend to lowered the tendency in having job related burnout (Schaufeli, Bakker, \& Salanova, 2006), which is also quite true within the academic workplace (Hakanen, Bakker, \& Schaufeli, 2006).

Bakker (2008) and his colleagues further described that a highly engaged individual should be

... proactive and show initiative, take responsibility for their own professional development, and to be committed to high quality performance standards ... (p. 188).

However, before an individual becomes engaged several antecedents should be present. Attridge (2009) suggests that before engagement occurs, certain workplace behavioral health practices should be practiced, such as: appropriate job design, adequate working conditions, resources, and support, and together with the positive (or healthy) organizational culture and leadership style. Besides these conditions, having adequate job autonomy (Bakker et al., 2008) and control over ones work are also precursors to becoming engaged (Mauno, Kinnunen, \& Ruokolainen, 2007).

As for job engagement, this can be defined as an individual's enthusiasm and involvement on his or her job (Roberts \& Davenport, 2002). In addition, job engagement is considered quite related to satisfaction (Wefald \& Downey, 2009) and the perceived job suitability (Warr \& Inceoglu, 2012). Roberts and Davenport (2002) further described that an engaged individual tend to work harder than his or her peers and would more likely to produce better performance as compared to others (p. 21). More specifically, positive job engagement leads to better task performance and OCB (Rich, Lepine, \& Crawford, 2010). Lastly, Saks (2006) clarifies that there are actually two different and separate types of general workplace engagement, namely: job and organizational engagement. This would mean that an employee might be actively involved in doing his or her job, while at the same time does not care to become involved with the organization or institution. However, there findings suggest that precursor to healthy engagements is the employees' perceived organization support from the institution (Rich et al., 2010; Saks, 2006) and from their immediate supervisors (Luthans \& Peterso, 2002).

\subsection{Perceived support}

As mentioned in the previous literature, perceived support is quite important in generating both positive workplace engagement and OCB. Perceived support actually includes the general belief that one's work is being 
valued by his or her organization (Rhoades \& Eisenberger, 2002). Yoon and Lim (1999) attributed perceived support to an individual's positive affectivity, such as with the likes of having a positive workplace outlook actually attracts relevant organizational support. Rhoades and Eisenberger (2002) further suggest that perceived support is reinforced with the presence of workplace equality. In addition, several studies all noted that the positive sense of support is quite important in retaining employees, in order words, lessen one's intention in leaving the organization (institution or company) (Aryee \& Chay, 2001; Djurkovic, McCormack, \& Casimir, 2008; Eisenberger, Stinglhamber, Vandenberghe, Sucharski, \& Rhoades, 2002), while at the same time, tends to lowers workplace aggression (Schat \& Kelloway, 2003) and job related stresses (Vagg \& Spielberger, 1998). In contrast, workplace inequality and bullying lowers the sense of perceived support (Aryee \& Chay, 2001; Djurkovic et al., 2008).

Lastly, with the notion that interactions within the workplace are instantaneous, various factors are actually ongoing at the same time. Within the academic workplace, creating a healthy workplace is quite important in establishing performance and what more could be more important than having teachers focusing on their teaching and refrain from doing negative deviant behaviors. Hence, the primary goal of the current paper is to understand the various interactions of perceived support and job engagement together with their impact towards organizational citizenship behavior and occurrence of counterproductive workplace behaviors.

\section{Design}

The current study primarily builds on the inter-relationships of perceived support (PS), job engagement (JE), organizational citizenship behavior (OCB), and the Taiwan model of counterproductive work behavior (CWB-T). The researchers proposed the model in hoping that occurrence of CWBs within the academic workplace can be further explain and understood. The following assumptions are noted: PS as the latent Independent Variable (IV), JE as the latent mediator, while OCB and CWB-T as the latent Dependent Variable (DV). A total of five hypotheses are proposed, namely (see figure 1 below for more details):

- Hypothesis 1 (H1): PS has significant positive effect on JE

- Hypothesis 2 (H2): JE has significant negative effect on CWB-T.

- Hypothesis 3 (H3): JE has significant positive effect on OCB.

- Hypothesis 4 (H4). JE mediates the PS to CWB-T relationship.

- Hypothesis 5 (H5). JE mediates the PS to OCB relationship.

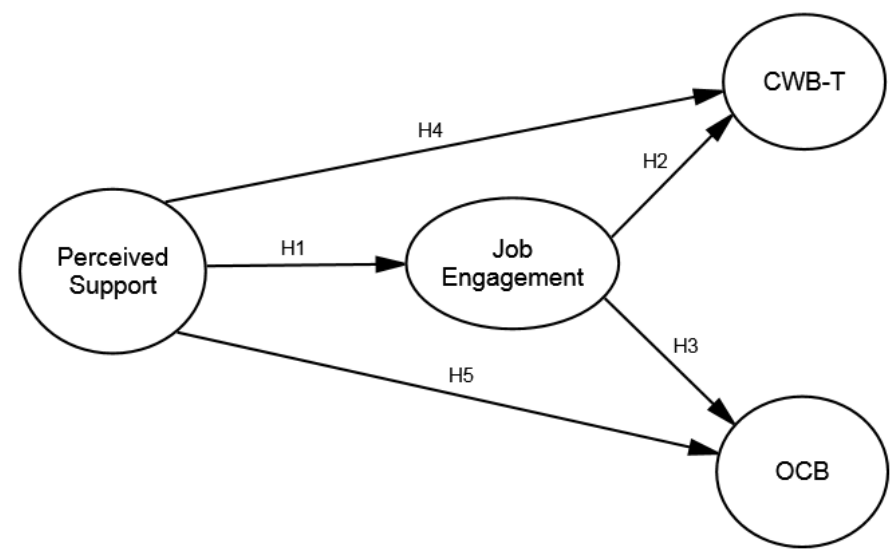

Figure 1. Hypothesized theoretical model

\subsection{Participants and procedure}

Participants of this study are volunteer elementary and high school teachers from the different regions in 
Hu, Y.-L., Hung, C.-H., \& Ching, G. S.

Taiwan. Schools were first strategically selected and a call for participant was distributed during the Spring semester of 2015. In the current study, both paper and online survey were used to augment data collection (Nulty, 2008; Sax, Gilmartin, \& Bryant, 2003). However, still majority of the respondents are from the localities with Northern Taiwan having 479 teachers or 45\% and Central Taiwan having 499 teachers or 49\%. In addition, the number of female and male participants is almost equal with Male teachers having 511 or $48 \%$ and Female teachers having 536 or $50 \%$.

For the various school types, Table 1 shows that participants are working in Elementary schools with 644 teachers or 60\%, Junior high schools with 323 teachers or 30\%, Senior high schools with 67 teachers or 6\%, and the remaining 40 teachers or $4 \%$ works in Vocational high schools. For the job positions, results show that Subject teachers comprises of 325 or 30\%, Teacher with class adviser duties with 352 or 33\%, Teacher with administrative duties with 304 or $28 \%$, Administrative staff with 62 or $6 \%$, and the remaining 31 or $3 \%$ are School principals. For the teachers' educational attainment, 500 or $47 \%$ are Bachelor degree holders, while the remaining teachers are Graduate degree holders. For the participants' school size, 722 or $67 \%$ worked at Small schools (12 class and below), 472 or $44 \%$ worked at Medium schools (13 to 48 class), and 481 or $45 \%$ worked at Large schools (49 class and above). Lastly, for the school location, 722 or $67 \%$ worked in Urban/City schools, while 280 or $26 \%$ worked in Rural schools.

\section{Table 1}

Participants' demographic background (N=1074)

\begin{tabular}{|c|c|c|}
\hline Items & $n$ & $\%$ \\
\hline \multicolumn{3}{|l|}{ Gender } \\
\hline Male & 511 & $48 \%$ \\
\hline Female & 536 & $50 \%$ \\
\hline \multicolumn{3}{|l|}{ School type } \\
\hline Elementary & 644 & 60 \\
\hline Junior high school & 323 & 30 \\
\hline Senior high school & 67 & 6 \\
\hline Vocational high school & 40 & 4 \\
\hline \multicolumn{3}{|l|}{ Position } \\
\hline Subject teacher & 325 & $30 \%$ \\
\hline Teacher w/ class adviser duties & 352 & $33 \%$ \\
\hline Teacher w/ administrative duties & 304 & $28 \%$ \\
\hline Administrative staff & 62 & $6 \%$ \\
\hline School Principal & 31 & $3 \%$ \\
\hline \multicolumn{3}{|l|}{ Highest educational attainment } \\
\hline Bachelor degree & 500 & $47 \%$ \\
\hline MA & 562 & $52 \%$ \\
\hline $\mathrm{PhD}$ & 12 & $1 \%$ \\
\hline \multicolumn{3}{|l|}{ School location } \\
\hline Northern Taiwan & 479 & $45 \%$ \\
\hline Central Taiwan & 499 & $46 \%$ \\
\hline Southern Taiwan & 89 & $8 \%$ \\
\hline Eastern Taiwan & 7 & $1 \%$ \\
\hline \multicolumn{3}{|l|}{ School size } \\
\hline Small (12 class and below) & 121 & $11 \%$ \\
\hline Medium (13 to 48 class) & 472 & $44 \%$ \\
\hline Large (49 class and above) & 481 & $45 \%$ \\
\hline \multicolumn{3}{|l|}{ District } \\
\hline Urban (city) & 722 & $67 \%$ \\
\hline Rural & 280 & $26 \%$ \\
\hline Remote (outer islands and/or mountain region) & 72 & $7 \%$ \\
\hline
\end{tabular}




\subsection{Research tools}

To collect the various data, several scales were used to measure the teachers' perceived support (PS), job engagement (JE), organizational citizenship behavior (OCB), and the Taiwan model of counterproductive work behavior (CWB-T).

Counterproductive Work Behavior (CWB-T) - To measure the CWB occurrences of teachers, the study make use of the CWB Taiwan (CWB-T) scale pioneered in several previous studies (Y.-L. Hu et al., 2015). Within the scale, there are a total of eight factors used to describe the various CWBs. The factors are as follows: time theft (TT, seven items), inappropriate use of resources (IUR, four items), inappropriate student-teacher relationship (ISR, seven items), inappropriate parent-teacher relationship (IPR, five items), lack of professionalism (LOP, six items), apathy (AP, six items), political tactics (PT, seven items), and reluctant to accept administrative duties (RAD, four items) (Y.-L. Hu et al., 2015, p. 71). Test-retest Cronbach (1951) Alpha reliabilities of the various CWB-T ranges from .72 to .90 (Ching et al., 2016; Y.-L. Hu et al., 2015, 2016), denoting a reliable instrument (Cohen, Manion, \& Morrison, 2007). Previous studies using CWB-T have consistently showed that TT and RAD as having the highest perceived deviant behaviors. While, the lowest CWB-T factors are IUR and IPR. For more information regarding the CWB-T factors and items, please read $\mathrm{Hu}$ et al. (2015).

Items for CWB-T are collected using a 4-point Likert (1932) type scale ranging from 0 ; denoting zero occurrence to 3; denoting always occurring. In addition, recoding was accomplished with the collected data following the suggestions of the original CWB-T study done by $\mathrm{Hu}$ et al. (2015). Data were recoded to 0 if original data is 0,1 , or 2 , while 1 was used when the original data is 3 . Hence, CWB-T items are now either $\boldsymbol{0}$ or 1, denoting none or possible CWB occurrence. Lastly, in order to lower the complexity of the computation, the mean scores of each of the eight factors are used as manifest variables into the proposed model.

Organization Citizenship Behaviors (OCB) - To measure the OCB of the teachers, the study uses the scale developed by Lee and Allen (2002), wherein two separate factors with four items each are collected. The two factors are OCB for individual (OCBI, four items) and OCB for organization (OCBO, four items). Cronbach (1951) Alpha reliabilities of the two factors are computed as .75 and .73 respectively. Items are collected using a 4-point Likert (1932) type scale ranging from 1 to 4 , denoting from never to always. Some sample items for OCBI are Willingly give your time to help others who have work-related problems and Adjust your work schedule to accommodate other employees' requests for time off. While, for OCBO are Attend functions that are not required but that help the organizational image and Defend the organization when other employees criticize it.

Job Engagement (JE) - As for the job engagement of teachers, the study uses the two factors scale designed by Saks (2006), wherein the Cronbach (1951) Alpha reliabilities is computed to be .84, denoting a reliable instrument (Cohen et al., 2007). For Saks (2006), JE can be separated into the actual work specific engagement (JE01, five items) and engagement within the organization (JE02, six items) factors. Items for JE are used to assess the participants' psychological presence in their job. Items are all collected using a 4-point Likert (1932) type scale ranging from 1 to 4 , denoting from strongly disagree to strongly agree. Some sample items for JE01 are I really "throw" myself into my job and a reverse coded item My mind often wanders and I think of other things when doing my job. While, sample items for JE02 are Being a member of this organization is very captivating and a reverse coded item I am really not into the "goings-on" in this organization.

Perceived Support (PS) - Two scales were used to measure the perceived support of Taiwan teachers, which includes perceived organizational support (POS, eight items) and perceived supervisor support (PSS, four items) as proposed by Eisenberger et al. (2002). Items for this scale are basically used to assess an individuals' perception on the value placed by the organization towards their well-being. Cronbach (1951) Alpha reliabilities 
Hu, Y.-L., Hung, C.-H., \& Ching, G. S.

are computed to be from .83 to .85 . Items are all collected using a 4-point Likert (1932) type scale ranging from $\boldsymbol{I}$ to $\mathbf{4}$, denoting from strongly disagree to strongly agree. Some sample items for POS are The organization holds my supervisor in high regard and The organization gives my supervisor the chance to make important decisions. While, sample items for PSS are My supervisor influences decisions made by upper management and My supervisor participates in decisions that affect the entire organization.

\subsection{Reliability and validity of the study}

Following the procedures of previous CWB-T studies, it is noted that within the issues of self-reported sensitive data gathering such as in organizational and work related topics, the issues of social desirability should be handled carefully (Podsakoff \& MacKenzie, 1997; Spector, 1987). Studies have noted that respondents tend to become somewhat bias when faced with the previous mentioned sensitive issues (Donaldson \& Grant-Vallone, 2002; Spector, 2006). To remedy this, within the current study, the researchers make use of the recoding scheme previously mentioned in section 3.2, wherein the initial Likert (1932) type scale ranging from $\boldsymbol{0}$ to 3 for the CWB-T; denoting the perceived occurrence of CWBs from zero to always, was recoded into either $\boldsymbol{O}$ for none occurrence and 1 for possible occurrence of CWBs. Then after recoding the various CWB-T items, Cronbach (1951) alpha reliabilities were recomputed resulting with slight increase of values. Hence, making the scale more reliable (Cohen et al., 2007).

In addition, the current study also make used of the 10 item short-form of the Marlowe-Crowne Social Desirability Scale (SDS) (Fisher \& Katz, 2000). After collecting the data with the other factors, correlation analysis with the different CWB-T factors was accomplished. Table 2 shows the various mean scores (including the overall mean score) of the SDS. While, Table 3 shows the various Pearson correlation values between the CWB-T factors and SDS. Results show that four of the CWB-T factors are slightly correlated with SDS. Such as IUR with $r=.083, p=.007, n=1074$, ISR with $r=.079, p=.010, n=1074$, LOP with $r=.081, p=.008, n=$ 1074 , and AP with $r=.082, p=.007, n=1074$. It is noted that within the previous CWB-T studies ISR and LOP repeatedly resulted with a slight correlation with SDS. In-depth analysis of these phenomenon are currently beyond the scope of this paper, however, researchers should be able to find this issue interesting for future studies. Lastly, as most of the CWB-T factors resulted in having no correlations with SDS, the data collected can now be used in the succeeding part of the analysis.

\section{Table 2}

Social desirability items $(N=1074)$

\begin{tabular}{llcc}
\hline Code & \multicolumn{1}{c}{ Factor/Items/Cronbach Alpha reliability } & $M$ & $S D$ \\
\hline SDS & \multicolumn{1}{c}{ Social Desirability Scale $(\alpha=.74)$} & 2.48 & 0.38 \\
SD01* & There have been times when I was quite jealous of the good fortune of others & 2.09 & 0.70 \\
SD02* & I sometimes feel resentful when I don't get my own way & 2.17 & 0.71 \\
SD03* & On a few occasions, I have given up doing something because I thought too little of & 2.21 & 0.82 \\
& my ability & 1.91 & 0.74 \\
SD04* & There have been occasions when I took advantage of someone & 1.92 & 0.79 \\
SD05* & I can remember "playing sick" to get out of something & 2.59 & 0.71 \\
SD06 & I have never been irked when people expressed ideas very different from my own & 2.83 & 0.66 \\
SD07 & I am always courteous, even to people who are disagreeable & 2.95 & 0.66 \\
SD08 & No matter who I'm talking to, I'm always a good listener & 3.03 & 0.58 \\
SD09 & I'm always willing to admit it when I make a mistake & 3.06 & 0.56 \\
\hline SD10 & When I don't know something I don't mind at all admitting it & &
\end{tabular}




\section{Table 3}

Correlational analysis with SDS $(N=1074)$

\begin{tabular}{lc}
\hline \multicolumn{1}{c}{ CWB-T Factors } & Correlation \\
\hline TT & .032 \\
IUR & $.083^{* *}$ \\
ISR & $.079^{* *}$ \\
IPR & .039 \\
LOP & $.081^{* *}$ \\
AP & $.082^{* *}$ \\
PT & .058 \\
RAD & -.002 \\
\hline Note. $* * p<.01$ (2-tailed). &
\end{tabular}

\subsection{Data analysis}

In order to test the proposed mediation model, the collected sample is now divided into two separate parts by random. $33 \%$ or 358 teachers are used in the measurement model for the Confirmatory Factor Analysis (CFA), while, the remaining $67 \%$ or 716 teachers are used in the structure model for the mediation test. Descriptive statistics is accomplished with the aid of the Statistical Package for the Social Sciences (SPSS) version 20 software. Composite reliability (CR) and average variance extracted (AVE) were used to prove the reliability and validity of the measurement model. At the same time, the structure model was used to explain the relationship together with the various effects among the latent variables. Structure equation modeling (SEM) was estimated using the maximum-likelihood method with the help of the Analysis of Moment Structures (AMOS) version 20 software (Arbuckle, 2011).

\section{Results and discussions}

\subsection{Descriptive statistics}

Descriptive statistics were accomplished on the collected with data. Tables 4 and 5 shows the various mean scores of the items, together with their overall mean scores, standard deviations, and Cronbach (1951) Alpha reliability values. Reliability check results with values ranging from .71 to .89 , denoting that the various scales are reliable (Cohen et al., 2007). Similar with previous CWB-T studies (Ching et al., 2016; Y.-L. Hu et al., 2016), Table 4 also shows that the factor $\boldsymbol{T T}$ has the highest perceived occurrence with a mean of 0.66 . In addition, within the factor $\boldsymbol{T T}$, the item Doing personal stuff while on duty has the highest mean with 0.86 . With the dichotomous nature of the recoded CWB-T items, a mean score of 0.86 would mean that respondents perceived the item as occurring around $86 \%$ of the time. This is followed by the item Being online (personal internet surfing; FB) while on duty with a mean score of 0.76 and the item Leaving without asking for leave with a mean score of 0.71 . This issue regarding $\boldsymbol{T T}$ has been repeatedly raised even in the previous studies conducted with Taiwan elementary and high school teachers, it can be noted that since there are no strict and obvious monitoring and sanctioning in placed (Y.-L. Hu et al., 2016), teachers might become relax and let down their guard against CWBs.

Besides time theft, the CWB-T factors $\boldsymbol{R A D}$ and $\boldsymbol{A P}$ both also have high overall mean scores with 0.61 and 0.60 respectively, denoting around $60 \%$ occurrences. Within the factor $\boldsymbol{R A D}$, the items Unwilling to undertake administrative responsibilities with a mean score of 0.76 and Miscommunication between teachers and administrators with a mean score of 0.70 , seems to be frequently occurring. These are actually quite disturbing since educational administration within the current age should not be limited to classroom teaching, but includes more complex roles (Bascia \& Young, 2001; Valli \& Buese, 2007). Furthermore, within the factor AP, the items Wrong use of educational resources with a mean score of 0.75 and Lacks teaching enthusiasm with a mean score 
Hu, Y.-L., Hung, C.-H., \& Ching, G. S.

of 0.74 , both are occurring more than $70 \%$ of the time. To explain this phenomenon, some studies mentioned that teachers are under a lot of stress (Burke, Greenglass, \& Schwarzer, 1996; Kyriacou, 1987; Kyriacou \& Chien, 2004), while signs of burnout might cause teachers to behave inappropriately. In addition, some other items such as Favoritism or discriminating specific students with mean score of 0.73 and Too few or too much assignments/class activities with mean score of 0.71 are also occurring with high frequencies.

In sum, as teaching can be considered as a stressful profession, nevertheless, it should not be the excuse for the occurrences of CWBs. Furthermore, many teachers might also consider that most of the deviant behaviors are so common and minor; it is quite alright to do a little mistake once in a while, which is but understandable. However, when the total number of common or minor CWBs is taken into consideration, the sheer volume of these negative incidents is also tantamount in causing seriously damage to the academic setting. More important, as students observe what is happening within the school, they can easily pickup and learn these CWBs.

\section{Table 4}

CWB-T items and overall mean scores $(N=1074)$

\begin{tabular}{|c|c|c|c|}
\hline Code & Factors/Items/Cronbach Alpha reliability & $M$ & $S D$ \\
\hline$\overline{\mathrm{TT}}$ & Time Theft $(\alpha=.81)$ & 0.66 & 0.30 \\
\hline TT01 & Lying about being sick & 0.45 & 0.50 \\
\hline TT02 & Leaving without asking for leave & 0.71 & 0.46 \\
\hline TT03 & Coming to school late and/or going home early & 0.69 & 0.46 \\
\hline TT04 & Asking for leave regardless of the work situation & 0.39 & 0.49 \\
\hline TT05 & Doing personal stuff while on duty & 0.86 & 0.34 \\
\hline TT06 & Being online (personal internet surfing; FB) while on duty & 0.76 & 0.43 \\
\hline TT07 & Chatting while on duty & 0.73 & 0.44 \\
\hline$\overline{\text { IUR }}$ & Inappropriate Use of Resources $(\alpha=.71)$ & 0.29 & 0.30 \\
\hline IUR01 & Waste of school's resources & 0.52 & 0.50 \\
\hline IUR02 & Occupying school's resources as if one's own property & 0.44 & 0.50 \\
\hline IUR03 & Stealing school resources & 0.11 & 0.31 \\
\hline$\underline{\text { IUR04 }}$ & Destruction of school's resources & 0.09 & 0.29 \\
\hline$\overline{\text { ISR }}$ & Inappropriate Student-teacher Relationship $(\alpha=.85)$ & 0.50 & 0.34 \\
\hline ISR01 & Favoritism or discriminating specific students & 0.73 & 0.45 \\
\hline ISR02 & Improper student punishment & 0.63 & 0.48 \\
\hline ISR03 & Mocking students & 0.51 & 0.50 \\
\hline ISR04 & Discrimination against students & 0.22 & 0.42 \\
\hline ISR05 & Deliberate singling out of specific students & 0.34 & 0.47 \\
\hline ISR06 & Focusing only on students with good grades and ignoring others & 0.51 & 0.50 \\
\hline ISR07 & Separated and cold towards students' problems & 0.58 & 0.49 \\
\hline IPR & Inappropriate Parent-teacher Relationship $(\alpha=.81)$ & 0.29 & 0.33 \\
\hline IPR01 & Deliberate concealment or providing misleading information & 0.37 & 0.48 \\
\hline IPR02 & Improper behavior in front of parents & 0.36 & 0.48 \\
\hline IPR03 & Encouraging parents to go against the school & 0.23 & 0.42 \\
\hline IPR04 & Conniving with parents & 0.13 & 0.34 \\
\hline IPR05 & Ignoring or unwilling to communicate with parents & 0.33 & 0.47 \\
\hline LOP & Lack of Professionalism $(\alpha=.84)$ & 0.55 & 0.36 \\
\hline LOP01 & Inadequate teacher preparation & 0.57 & 0.49 \\
\hline LOP02 & Not following proper curriculum & 0.55 & 0.50 \\
\hline LOP03 & Saying improper things during class & 0.50 & 0.50 \\
\hline LOP04 & Too few or too much assignments/class activities & 0.71 & 0.46 \\
\hline LOP05 & Casual checking of students' assignments & 0.41 & 0.49 \\
\hline LOP06 & Improper use of teaching pedagogy (such as too much movie time) & 0.54 & 0.50 \\
\hline$\overline{\mathrm{AP}}$ & Apathy $(\alpha=.82)$ & 0.60 & 0.34 \\
\hline AP01 & Unwilling to undergo tutoring & 0.40 & 0.49 \\
\hline AP02 & Lacks teaching enthusiasm & 0.74 & 0.44 \\
\hline AP03 & Wrong use of educational resources & 0.75 & 0.43 \\
\hline AP04 & Lacks professional content knowledge & 0.48 & 0.50 \\
\hline AP05 & Unwilling to participate in professional development workshops & 0.60 & 0.49 \\
\hline AP06 & Lacks the motivation to join professional development programs & 0.61 & 0.49 \\
\hline
\end{tabular}


Shifting between CWB and OCB: The effects of workplace support and engagement

Table 4 ... continued

\begin{tabular}{|c|c|c|c|}
\hline Code & Factors/Items/Cronbach Alpha reliability & $M$ & $S D$ \\
\hline$\overline{\mathrm{PT}}$ & Political Tactics $(\alpha=.89)$ & 0.46 & 0.37 \\
\hline PT01 & Gossiping & 0.73 & 0.44 \\
\hline PT02 & Spreading wrong/bad information & 0.43 & 0.49 \\
\hline PT03 & Improver verbal conduct & 0.35 & 0.48 \\
\hline PT04 & Deliberate neglect or ignoring others & 0.51 & 0.50 \\
\hline PT05 & Deliberate singling out others & 0.42 & 0.49 \\
\hline PT06 & Forming small groups/alliances to go against others & 0.45 & 0.50 \\
\hline PT07 & Convincing others to go against the school & 0.35 & 0.48 \\
\hline RAD & Reluctant to accept Administrative Duties $(\alpha=.78)$ & 0.61 & 0.37 \\
\hline RAD01 & Unwilling to cooperate with school administration & 0.52 & 0.50 \\
\hline RAD02 & Going against all educational reforms & 0.49 & 0.50 \\
\hline RAD03 & Unwilling to undertake administrative responsibilities & 0.76 & 0.43 \\
\hline RAD04 & Miscommunication between teachers and administrators & 0.70 & 0.46 \\
\hline
\end{tabular}

Note. Mean scores recoded into either 0 - no occurrence, 1 - possible occurrence.

For Table 5, results show that teachers perceived POS, PSS, JE01, JE02, OCBI, and OCBO to occurring within a moderate to high frequency with overall mean scores ranging from 2.65 to 2.87 . Results actually are quite promising since, most teachers noted that $\boldsymbol{P S S}$ and $\boldsymbol{O C B I}$ to be the highest. Further analysis reveals that within the PSS the item The organization gives my supervisor the freedom to determine how to treat me with mean score of 2.98, The organization consults my supervisor when deciding on new policies and procedures with a mean score of 2.95, The organization supports decisions made by my supervisor with a mean score of 2.93, and The organization allows my supervisor to run things the way he/she wants with a mean score of 2.91. Such findings clearly display that schools in Taiwan are quite supportive of their administrators and teachers.

Similarly, for the teachers' job engagement, Table 5 also shows that the reversely coded item My mind often wanders and I think of other things when doing my job with mean score of 2.95 and I am really not into the "goings-on" in this organization with mean score of 2.94, and the items Sometimes I am so into my job that I lose track of time with mean score of 2.93 and I am highly engaged in this job with mean score of 2.92, both denotes moderately high involvement.

\section{Table 5}

Organizational support, job engagement, and organizational citizenship behavior items mean scores $(N=1074)$

\begin{tabular}{|c|c|c|c|c|}
\hline Code & Factors/Items/Cronbach Alpha reliability & $n$ & $M$ & $S D$ \\
\hline POS & Perceived Organizational Support $(\alpha=.84)$ & 1074 & 2.85 & 0.43 \\
\hline POS01 & The organization holds my supervisor in high regard & & 2.70 & 0.65 \\
\hline POS02 & The organization gives my supervisor the chance to make important decisions & & 2.72 & 0.65 \\
\hline POS03 & The organization values my supervisor's contributions & & 2.83 & 0.68 \\
\hline POS04 & The organization gives my supervisor the authority to try new things & & 2.78 & 0.63 \\
\hline POS05 & The organization supports decisions made by my supervisor & & 2.93 & 0.53 \\
\hline POS06 & The organization allows my supervisor to run things the way he/she wants & & 2.91 & 0.50 \\
\hline POS07 & The organization consults my supervisor when deciding on new policies $\&$ procedures & & 2.95 & 0.62 \\
\hline POS08 & The organization gives my supervisor the freedom to determine how to treat me & & 2.98 & 0.70 \\
\hline PSS & Perceived Supervisor Support $(\alpha=.86)$ & 1074 & 2.75 & 0.56 \\
\hline PSS01 & My supervisor influences decisions made by upper management & & 2.81 & 0.59 \\
\hline PSS02 & My supervisor participates in decisions that affect the entire organization & & 2.72 & 0.69 \\
\hline PSS03 & If my supervisor decided to quit, the organization would try to persuade him/her to stay & & 2.73 & 0.59 \\
\hline PSS04 & Even if my supervisor did well, the organization would fail to notice & & 2.88 & 0.65 \\
\hline JE01 & Job Engagement $(\alpha=.76)$ & 575 & 2.87 & 0.45 \\
\hline JEn01 & I really "throw" myself into my job & & 2.81 & 0.59 \\
\hline JEn02 & Sometimes I am so into my job that I lose track of time & & 2.93 & 0.62 \\
\hline JEn03 & This job is all consuming; I am totally into it & & 2.73 & 0.72 \\
\hline JEn04* & My mind often wanders and I think of other things when doing my job & & 2.95 & 0.56 \\
\hline JEn05 & I am highly engaged in this job & & 2.92 & 0.68 \\
\hline
\end{tabular}


Table 5 ... continued

\begin{tabular}{|c|c|c|c|c|}
\hline Code & Factors/Items/Cronbach Alpha reliability & $n$ & $M$ & $S D$ \\
\hline JE02 & Organizational Engagement $(\alpha=.89)$ & 575 & 2.65 & 0.49 \\
\hline OEn01 & Being a member of this organization is very captivating & & 2.66 & 0.61 \\
\hline OEn02 & The most exciting for me is getting involved with things happening in this organization & & 2.44 & 0.62 \\
\hline $\mathrm{OEn} 03 *$ & I am really not into the "goings-on" in this organization & & 2.94 & 0.64 \\
\hline OEn04 & Being a member of this organization make me come "alive" & & 2.61 & 0.60 \\
\hline OEn05 & Being a member of this organization is exhilarating for me & & 2.57 & 0.61 \\
\hline OEn06 & I am highly engaged in this organization & & 2.67 & 0.59 \\
\hline OCBI & Organizational Citizenship Behavior - Individual $(\alpha=.80)$ & 575 & 2.85 & 0.39 \\
\hline OCBI01 & Willingly give your time to help others who have work-related problems & & 2.89 & 0.56 \\
\hline $\mathrm{OCBI02}$ & Adjust your work schedule to accommodate other employees' requests for time off & & 2.74 & 0.55 \\
\hline OCBI03 & Go out of the way to make newer employees feel welcome in the work group & & 2.89 & 0.43 \\
\hline OCBI04 & Assist others with their duties & & 2.88 & 0.44 \\
\hline$\overline{\mathrm{OCBO}}$ & Organizational Citizenship Behavior - Organization $(\alpha=.76)$ & 575 & 2.83 & 0.39 \\
\hline OCBO01 & Attend functions that are not required but that help the organizational image & & 2.91 & 0.52 \\
\hline OCBO02 & Defend the organization when other employees criticize it & & 2.90 & 0.46 \\
\hline OCBO03 & Offer ideas to improve the functioning of the organization & & 2.82 & 0.50 \\
\hline OCBO04 & Take action to protect the organization from potential problems & & 2.70 & 0.55 \\
\hline
\end{tabular}

Note. Data collected using 4-point Likert scale. *Reverse coded items.

Lastly, for the correlations among the various factors, Table 6 shows that the various CWB-T factors are quite correlated with each other. This would mean the occurrence of some CWBs would also have the tendency for other deviant behaviors to occur (denoted by the lightly shaded values in the table). In contrast for the correlations of the various positive factors, such as PS, JE, and OCB; Table 6 shows that these factors are quite correlated with each other (denoted by the darkly shaded values in the table). This actually indicates that the positive atmosphere has the tendency to promote each other. As for the inter-correlations between the negative CWB-T and positive PS, JE, and OCB, results show that there are significant negative correlations among the two groups of factors. These results would somehow indicate that the groups are occurring in opposition with each other. In other words, an increased in CWB-T would signify a decrease in PS, JE, and OCB.

Table 6

Correlational analysis among the factors

\begin{tabular}{|c|c|c|c|c|c|c|c|c|c|c|c|c|c|c|}
\hline & TT & IUR & ISR & IPR & LOP & AP & PT & RAD & POS & PSS & $\mathrm{JE}$ & $\mathrm{OE}$ & OCBI & OCBO \\
\hline TT & 1 & & & & & & & & & & & & & \\
\hline IUR & $.623 * *$ & 1 & & & & & & & & & & & & \\
\hline ISR & $.591 * *$ & $.635 * *$ & 1 & & & & & & & & & & & \\
\hline IPR & $.504 * *$ & $.630^{* *}$ & $.675^{* *} *$ & 1 & & & & & & & & & & \\
\hline LOP & $.584 * *$ & $.611 * *$ & $.719 * *$ & $.670 * *$ & 1 & & & & & & & & & \\
\hline AP & $.536 * *$ & $.542 * *$ & $.633 * *$ & $.603 * *$ & $.740 * *$ & 1 & & & & & & & & \\
\hline PT & $.498 * *$ & $.513 * *$ & $.614 * *$ & $.638 * *$ & $.625^{* *}$ & $.642 * *$ & 1 & & & & & & & \\
\hline RAD & $.475 * *$ & $.476^{* *}$ & $.526 * *$ & $.551 * *$ & $.612 * *$ & $.682 * *$ & $.685 * *$ & 1 & & & & & & \\
\hline POS & $-.126 * *$ & $-.189 * *$ & $-.128 * *$ & $-.171 * *$ & $-.127 * *$ & $-.206 * *$ & $-.192 * *$ & $-.204 * *$ & 1 & & & & & \\
\hline PSS & $-.127 * *$ & $-.145^{* *}$ & $-.118 * *$ & $-.188 * *$ & $-.129 * *$ & $-.201 * *$ & $-.176 * *$ & $-.185^{* *}$ & $.779 * *$ & 1 & & & & \\
\hline JE & $-.255 * *$ & $-.315^{* *} *$ & $-.223 * *$ & $-.241 * *$ & $-.229 * *$ & $-.290 * *$ & $-.267 * *$ & $-.281 * *$ & $.210 * *$ & $.269 * *$ & 1 & & & \\
\hline $\mathrm{OE}$ & $-.290 * *$ & $-.314 * *$ & $-.239 * *$ & $-.244 * *$ & $-.251 * *$ & $-.330 * *$ & $-.249 * *$ & $-.274 * *$ & $.569 * *$ & $.590 * *$ & $.512 * *$ & 1 & & \\
\hline OCBI & $-.203 * *$ & $-.222 * *$ & $-.160 * *$ & $-.169 * *$ & $-.170 * *$ & $-.231 * *$ & $-.239 * *$ & $-.256 * *$ & $.383 * *$ & $.411 * *$ & $.476^{* * *}$ & $.459 * *$ & 1 & \\
\hline OCBO & $-.244 * *$ & $-.270 * *$ & $-.213 * *$ & $-.188 * *$ & $-.227 * *$ & $-.253 * *$ & $-.234 * *$ & $-.265^{* * *}$ & $.461 * *$ & $.476 * *$ & $.518 * *$ & $.620 * *$ & $.699 * *$ & 1 \\
\hline
\end{tabular}

\subsection{Preliminary Analyses}

Means, standard deviations, and zero-order correlations for the various factors are presented in Tables 4 to 6 . Since the number of items of each of the factors are not equal, to make the computation less complex, mean scores of each of the factors were used in the model analysis. Multivariate normality test was used to examine whether the data met the normality assumptions underlying the maximum-likelihood procedure used to test the models in the present study. The results of the multivariate normality test indicated that the data were multivariate normal, multivariate kurtosis was 12.30. Therefore, maximum-likelihood method was appropriate (Arbuckle, 2011). 


\subsection{Measurement Model}

Prior to the structural model test, Anderson and Gerbing (1988) performed a confirmatory factor analysis to examine whether the measurement model provides an acceptable fit to the data. Within their study, they noted that once an acceptable measurement model is developed that is the time the structural model can be tested. Six model fit indices were used to assess the goodness of fit of the model (Byrne, 2009; L. T. Hu \& Bentler, 1999; Tucker \& Lewis, 1973). The various fit indicators are as such: the Goodness of Fit Index (GFI; values $>0.90$ indicating good fit), the Comparative Fit Index (CFI; values $>0.90$ indicating good fit), the Tucker-Lewis Index (TLI; values $>0.90$ indicating good fit), the Non-normed Fit Index (NFI; values $>0.90$ indicating good fit), and the Root Mean-Square Error of Approximation (RMSEA; values <0.08 indicating good fit), and the Standardized Root Mean Square Residual (SRMR; values $<0.08$ indicating good fit).

Using the statistical method of SEM, the test of the measurement model resulted in a relatively good fit to the data with $\chi^{2}=189.74^{* * *}, d f=71, \mathrm{GFI}=.93, \mathrm{CFI}=.96, \mathrm{TLI}=.95, \mathrm{NFI}=.94, \mathrm{RMSEA}=.068, \mathrm{SRMR}=.037$. All of which of the standardized loadings of the measured variables on the latent variables were statistically significant with $p<.001$ (see Table 7). In addition, it is computed that the CR of the latent variables with values ranging from .77 .93 and with AVE values ranging from.63 .77 (see Table 8), denoting acceptable ranges (Fornell \& Larcker, 1981; Hair, Black, Babin, \& Anderson, 2010). Therefore, all of the latent variables appear to have been adequately operationalized by their respective indicators. In addition, most of the correlations among the independent latent variables, the mediator latent variable, and dependent latent variables were statistically significant with $p<.001$ (see Table 9).

Table 7

Model Fit Indices

\begin{tabular}{cccc}
\hline Indices & Measurement model & Structural model & Criteria \\
\hline$n$ & 358 & 716 & \\
$\chi^{2}$ & $189.74^{* * *}$ & $345.36^{* * *}$ & \\
$d f$ & 71 & 72 & $>.90$ \\
GFI & .950 & .925 & $>.90$ \\
CFI & .961 & .955 & $>.90$ \\
TLI & .950 & .962 & $>.90$ \\
NFI & .940 & .933 & $<.08$ \\
RMSEA & .068 & .071 & $<.08$ \\
SRMR & .037 & .041 &
\end{tabular}

\section{Table 8}

Factor loadings for the measurement model (33\% sample, $n=358$ )

\begin{tabular}{|c|c|c|c|c|c|}
\hline Factors/Items & Standardized factor loading & $S E$ & $t$ & AVE & $\mathrm{CR}$ \\
\hline CWB- T & & & & .63 & .93 \\
\hline TT & .68 & & & & \\
\hline IUR & .73 & 0.08 & 12.72 & & \\
\hline ISR & .83 & 0.09 & 14.30 & & \\
\hline IPR & .81 & 0.09 & 14.05 & & \\
\hline LOP & .85 & 0.10 & 14.53 & & \\
\hline AP & .84 & 0.09 & 14.40 & & \\
\hline PT & .80 & 0.10 & 13.87 & & \\
\hline RAD & .77 & 0.10 & 13.38 & & \\
\hline OCB & & & & .70 & .82 \\
\hline OCB-Individual & .79 & & & & \\
\hline OCB-Organization & .88 & 0.08 & 14.06 & & \\
\hline
\end{tabular}


Hu, Y.-L., Hung, C.-H., \& Ching, G. S.

Table 8 ... continued

\begin{tabular}{|c|c|c|c|c|c|}
\hline Factors/Items & Standardized factor loading & $S E$ & $t$ & AVE & CR \\
\hline Perceived support (PS) & & & & .77 & .87 \\
\hline POS & .87 & & & & \\
\hline PSS & .89 & 0.16 & 9.43 & & \\
\hline Job engagement (JE) & & & & .63 & .77 \\
\hline JE01 & .81 & & & & \\
\hline JE02 & .78 & 0.07 & 14.20 & & \\
\hline
\end{tabular}

Note. All standardized factor loading is significant at the .001 level.

Table 9

Latent correlations matrix for the measurement model (33\% sample, $n=358$ )

\begin{tabular}{lcccc}
\hline \multicolumn{1}{c}{ Latent Variables } & $(1)$ & $(2)$ & $(3)$ & $(4)$ \\
\hline (1) CWB-T & 1 & & & \\
(2) OCB & -.34 & 1 & 1 & \\
(3) Job Engagement (JE) & -.32 & .66 & .41 & 1 \\
(4) Perceived Support (PS) & -.24 & .57 & \\
\hline
\end{tabular}

Note. All latent correlation is significant at the .001 level (2-tailed).

\subsection{Structural model for testing mediated effects}

In testing the mediated effects of the structural model, the statistical method of SEM was used. Within the mediated model, PS was taken as the latent IV, JE as the latent mediator, while OCB and CWB-T as the latent DV. After the computation, SEM results indicate a good model fit with $\chi^{2}=345.36^{* * *}, d f=72, \mathrm{GFI}=.93$, CFI $=.96, \mathrm{TLI}=.96, \mathrm{NFI}=.93, \mathrm{RMSEA}=.071, \mathrm{SRMR}=.041$ (see Figure 2$).$ In addition, path effects (or direct effects) are medium and significant with $p<.001$ (see Table 10). In addition, MacKinnon, Lockwood, Hoffmann, West, and Sheets (2002) assessed many approaches to examine mediation considering Type I error and statistical power. They suggested that the method used by Baron and Kenny (1986) has the least power, while other suggested the Sobel (1982) test to examine the significance of mediation effect. However, there is evidence that the distribution of mediation effect is not normal (Bollen \& Stine, 1990; MacKinnon \& Dwyer, 1993; C. A. Stone \& Sobel, 1990), and the utilization of a significance test, such as the Sobel test, which assumes a normal distribution when examining the mediation effect, is not appropriate. In answering the various uncertainty, recently, Shrout and Bolger (2002) suggested the bootstrap method as a better way to examine mediation. Within the bootstrap method, the model acquires $95 \%$ of the confidence intervals (CI) for the indirect effect by resampling procedure. Based on the central limit theorem, bootstrap method is robust even for models with distribution of mediation effect is not normal. As suggested by Shrout and Bolger (2002), bootstrap procedure were accomplished using the AMOS program.

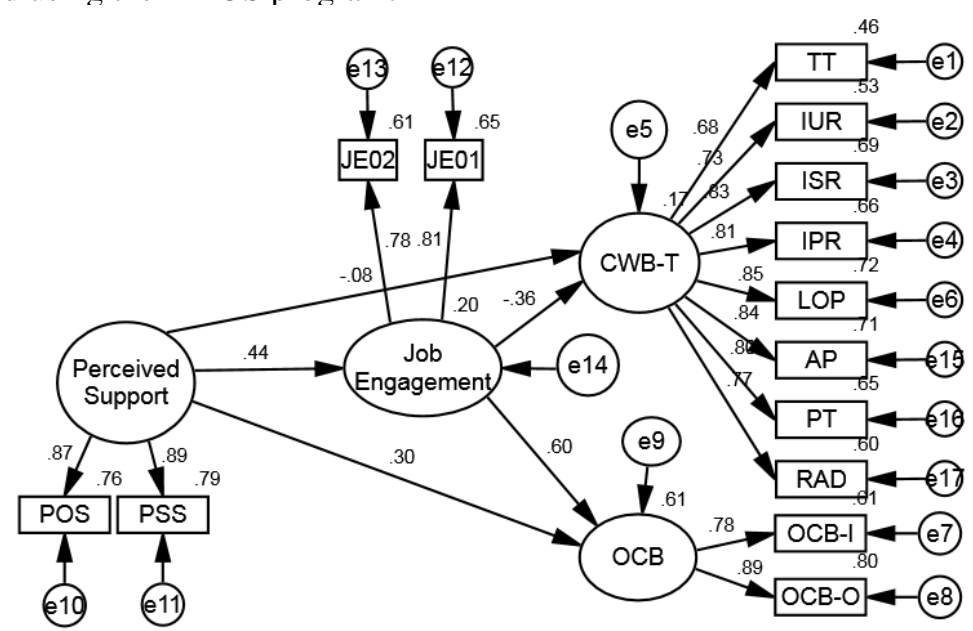

Figure 2. Structure equation model with maximum likelihood estimates (standardized) 
Results of the mediation test shows that the indirect effect from PS to CWB-T is -.16 (see Table 10), while the $95 \% \mathrm{CI}$ for the estimates of the indirect effects with values ranging from -.259 -.097 (not including zero) with statistically significant mediation effect at .05 level. This result suggests that within the Taiwan academic setting, JE plays an important role of mediator between PS and CWB-T. As the PS to CWB-T path is not significant, however, according to Baron and Kenny (1986) this can be considered a complete mediation. Hence, $\mathbf{J E}$ is a very important mediator for decreasing the deviant behaviors on school workplace. Furthermore, the total effect; which is the summation of direct effect and indirect effect, the total effect from PS to CWB-T is -.25. While the $95 \%$ CI for total effects with values ranging from -.347 -.135 (not including zero) with the total effect statistically significant at the .05 level.

On the other hand, the indirect effect from PS to OCB is .27. The 95\% CI for the estimates of the indirect effects with values ranging from .171 .402 (not including zero), and then it can be concluded that the mediation effect is statistically significant at the .05 level. Therefore, within the Taiwan academic setting, JE plays the role of mediator between PS and OCB. While the total effect from PS to OCB is .57, the 95\% CI for total effects with values ranging from .431 .671 (not including zero) with the total effect statistically significant at the .05 level (see Table 10).

\section{Table 10}

Bootstrap Analysis of Structural Model (67\% sample, $n=716$ )

\begin{tabular}{clcc}
\hline Hypothesis & \multicolumn{1}{c}{ Path } & Standardized coefficient & $95 \%$ CI \\
\hline H1 & PS $\rightarrow$ JE & $.44^{* * *}$ & \\
H2 & JE $\rightarrow$ CWB-T & $-.36^{* * *}$ & \\
H3 & JE $\rightarrow$ OCB & $.60^{* * *}$ & $-.259 \sim-.097$ \\
H4 & PS $\rightarrow$ JE $\rightarrow$ CWB-T & -.16 & $.171 \sim .402$ \\
H5 & PS $\rightarrow$ JE $\rightarrow$ OCB & .27 & $-.347 \sim-.135$ \\
& Total effect on CWB-T & -.25 & $.431 \sim .671$ \\
\hline
\end{tabular}

Note. $* * * p<.001$.

\section{Conclusion}

The current study portrays the various underlying indicators of both OCB and CWB-T within the academic setting. Results of the model testing noted the support of the proposed hypotheses. While the test of mediation confirmed the mediator role of job engagement between perceived support and counterproductive work behaviors. At the same time, the test of mediation also confirmed the mediator role of job engagement between perceived support and organizational citizenship behavior. Note that one path is producing a positive effect, while the other a negative effect. Therefore, in order for the academic setting to be a healthy workplace, it is important that a positive atmosphere of support be encouraged. Furthermore, policy makers (including school administrators) should focus on improving and promoting various support strategies from both the school organization and school administrators (supervisors) and reinforce the job engagement of teachers. Lastly, as per suggestion of Baron and Kenny (1986), the paths of direct effect is still significant, hence, the mediation path within the proposed model; OCB can be considered as partial mediation. Therefore, the current study suggests that there may be other effective mediator that can be taken into consideration in future studies.

Acknowledgement: This work is supported in part by the Taiwan Ministry of Science and Technology projects 103-2410-H-004-143 and 104-2410-H-004-151-SS2.

\section{References}

Anderson, J. C., \& Gerbing, D. W. (1988). Structural equation modeling in practice: A review and recommended two-step approach. Psychological Bulletin, 103(3), 411-423. https://doi.org/10.1037/0033-2909.103.3.411 
Hu, Y.-L., Hung, C.-H., \& Ching, G. S.

Arbuckle, J. L. (2011). IBM SPSS Amos 20 user's guide. Armonk, NY: IBM.

Aryee, S., \& Chay, Y. W. (2001). Workplace justice, citizenship behavior, and turnover intentions in a union context: Examining the mediating role of perceived union support and union instrumentality. Journal of Applied Psychology, 86(1), 154-160. https://doi.org/10.1037/0021-9010.86.1.154

Attridge, M. (2009). Measuring and managing employee work engagement: A review of the research and business literature. Journal of Workplace Behavioral Health, 24(4), 383-398. https://doi.org/10.1080/15555240903188398

Ayoko, O. B., Callan, V. J., \& Härtel, C. E. J. (2003). Workplace conflict, bullying, and counterproductive behaviors. The International Journal of Organizational Analysis, 11(4), 283-301. https://doi.org/10.1108/eb028976

Bakker, A. B., \& Demerouti, E. (2008). Towards a model of work engagement. Career Development International, 13(3), 209-223. https://doi.org/10.1108/13620430810870476

Bakker, A. B., Schaufeli, W. B., Leiter, M. P., \& Taris, T. W. (2008). Work engagement: An emerging concept in occupational health psychology. Work and Stress, 22(3), 187-200. https://doi.org/10.1080/02678370802393649

Baron, R. M., \& Kenny, D. A. (1986). The moderator-mediator variable distinction in social psychological research: Conceptual, strategic, and statistical considerations. Journal of Personality and Social Psychology, 51(6), 1173-1182. https://doi.org/10.1037/0022-3514.51.6.1173

Bascia, N., \& Young, B. (2001). Women's careers beyond the classroom: Changing roles in a changing world. Curriculum Inquiry, 31(3), 271-302. https://doi.org/10.1111/0362-6784.00198

Berry, C. M., Ones, D. S., \& Sackett, P. R. (2007). Interpersonal deviance, organizational deviance, and their common correlates: A review and meta-analysis. Journal of Applied Psychology, 92(2), 410-424. https://doi.org/10.1037/0021-9010.92.2.410

Bogler, R., \& Somech, A. (2004). Influence of teacher empowerment on teachers' organizational commitment, professional commitment and organizational citizenship behavior in schools. Teaching and Teacher Education, 20(3), 277-289. https://doi.org/10.1016/j.tate.2004.02.003

Bollen, K. A., \& Stine, R. A. (1990). Bootstrapping goodness-of-fit measures in structural equation models. Sociological Methods and Research, 21(2), 205-229. https://doi.org/10.1177/0049124192021002004

Borman, W. C., \& Motowidlo, S. J. (1997). Task performance and contextual performance: The meaning for personnel selection research. Human Performance, 10(2), 99-109. https://doi.org/10.1207/s15327043hup1002_3

Borman, W. C., \& Motowidlo, S. M. (1993). Expanding the criterion domain to include elements of contextual performance. In N. Schmitt \& W. C. Borman (Eds.), Personnel selection in organizations (pp. 71-98). San Francisco: Jossey-Bass.

Bowling, N. A., \& Gruys, M. L. (2010). Overlooked issues in the conceptualization and measurement of counterproductive work behavior. Human Resource Management Review, 20(1), 54-61. https://doi.org/10.1016/j.hrmr.2009.03.008

Britt, T. W., \& Jex, S. M. (2015). Thriving under stress: Harnessing demands in the workplace. New York, NY: Oxford.

Burke, R. J., Greenglass, E. R., \& Schwarzer, R. (1996). Predicting teacher burnout over time: Effects of work stress, social support, and self-doubts on burnout and its consequences. Anxiety, Stress, \& Coping, 9(3), 261-275. https://doi.org/10.1080/10615809608249406

Byrne, B. M. (2009). Structural equation modeling with AMOS: Basic concepts, applications, and programming (2nd ed.). New York, NY: Taylor Francis.

Chang, K., Nguyen, B., Cheng, K.-T., Kuo, C.-C., \& Lee, I. (2016). HR practice, organisational commitment \& citizenship behaviour: A study of primary school teachers in Taiwan. Employee Relations, 38(6), 907-926. https://doi.org/10.1108/ER-12-2015-0218

Ching, G. S., Tsay, W.-R., Hu, Y.-L., \& Hung, C.-H. (2016). Counterproductive work behaviors within academic institutions: A myth or a reality. International Journal of Research Studies in Psychology, 6(1), 1-14. https://doi.org/10.5861/ijrsp.2016.1629

Christ, O., Van Dick, R., Wagner, U., \& Stellmacher, J. (2003). When teachers go the extra mile: Foci of organisational identification as determinants of different forms of organisational citizenship behaviour among schoolteachers. British Journal of Educational Psychology, 73(3), 329-341. https://doi.org/10.1348/000709903322275867

Chughtai, A. A., \& Zafar, S. (2006). Antecedents and consequences of organizational commitment among Pakistani university teachers. Applied Human Resource Management Research, 11(1), 39-64.

Cohen, L., Manion, L., \& Morrison, K. (2007). Research methods in education. New York: Routledge.

Cronbach, L. J. (1951). Coefficient alpha and the internal structure of tests. Psychometrika, 16, 197-334. 
Shifting between CWB and OCB: The effects of workplace support and engagement

https://doi.org/10.1007/BF02310555

Dalal, R. S. (2005). A meta-analysis of the relationship between organizational citizenship behavior and counterproductive work behavior. Journal of Applied Psychology, 90(6), 1241-1255. https://doi.org/10.1037/0021-9010.90.6.1241

Djurkovic, N., McCormack, D., \& Casimir, G. (2008). Workplace bullying and intention to leave: The moderating effect of perceived organisational support. Human Resource Management Review, 18(4), 405-422. https://doi.org/10.1111/j.1748-8583.2008.00081.x

Dobbins, G. H., Pence, E. C., Orban, J. A., \& Sgro, J. A. (1983). The effects of sex on the leader and sex of the subordinate on the use of organizational control policy. Organizational Behavior and Human Performance, 32, 325-343. https://doi.org/10.1016/0030-5073(83)90154-X

Donaldson, S. I., \& Grant-Vallone, E. J. (2002). Understanding self-report bias in organizational behavior research. Journal of Business and Psychology, 17(2), 245-260. https://doi.org/10.1023/A:1019637632584

Eisenberger, R., Stinglhamber, F., Vandenberghe, C., Sucharski, I. L., \& Rhoades, L. (2002). Perceived supervisor support: contributions to perceived organizational support and employee retention. Journal of Applied Psychology, 87(3), 565-573. https://doi.org/10.1037/0021-9010.87.3.565

Fisher, R., \& Katz, J. E. (2000). Social-desirability bias and the validity of self-reported values. Psychology \& Marketing, 17(February), 105-120.

Fornell, C., \& Larcker, D. F. (1981). Evaluating structural equation models with unobservable variables and measurement error. Journal of Marketing Research, 18(1), 39-50. https://doi.org/10.2307/3151312

Fox, S., \& Stallworth, L. E. (2010). The battered apple: An application of stressor-emotion-control/support theory to teachers' experience of violence and bullying. Human Relations, 63(7), 927-954. https://doi.org/10.1177/0018726709349518

Gruys, M. L., \& Sackett, P. R. (2003). Investigating the dimensionality of counterproductive work behavior. International Journal of Selection and Assessment, 11(1), 30-42. https://doi.org/10.1111/1468-2389.00224

Hair, J. F., Jr., Black, W. C., Babin, B. J., \& Anderson, R. E. (2010). Multivariate data analysis: A global perspective. Upper Saddle, NJ: Pearson.

Hakanen, J. J., Bakker, A. B., \& Schaufeli, W. B. (2006). Burnout and work engagement among teachers. Journal of School Psychology, 43(6), 495-513. https://doi.org/10.1016/j.jsp.2005.11.001

Hershcovis, M. S., Turner, N., Barling, J., Arnold, K. A., Dupré, K. E., Inness, M., et al. (2007). Predicting workplace aggression: A meta-analysis. Journal of Applied Psychology, 92(1), 228-238. https://doi.org/10.1037/0021-9010.92.1.228

Hogan, J., Rybicki, S. L., \& Borman, W. C. (1998). Relations between contextual performance, personality, and occupational advancement. Human Performance, 11(2-3), 189-207. https://doi.org/10.1080/08959285.1998.9668031

Hu, L. T., \& Bentler, P. M. (1999). Cutoff criteria for fit indexes in covariance structure analysis: Conventional criteria versus new alternatives. Structural Equation Modeling: A Multidisciplinary Journal, 6(1), 1-55. https://doi.org/10.1080/10705519909540118

Hu, Y.-L., Hung, C.-H., \& Ching, G. S. (2015). Examining the counterproductive work behaviors within Taiwan academic setting: A pilot study. Higher Education Evaluation and Development, 9(1), 63-82. https://doi.org/10.6197/HEED.2015.0901.04

Hu, Y.-L., Hung, C.-H., \& Ching, G. S. (2016). The impact of monitoring and sanctioning and perceived loafing towards revenge motive and tendency to commit counterproductive work behaviors within the academic workplace. International Journal of Research Studies in Management, 5(2), 79-95. https://doi.org/10.5861/ijrsm.2016.1627

Klotz, A. C., \& Buckley, M. R. (2013). A historical perspective of counterproductive work behavior targeting the organization. Journal of Management History, 19(1), 114-132. https://doi.org/10.1108/17511341311286222

Kossek, E. E., Pichler, S., Bodner, T., \& Hammer, L. B. (2011). Workplace social support and work-family conflict: A meta-analysis clarifying the influence of general and work-family-specific supervisor and organizational support. Personnel Psychology, 64(2), 289-313. https://doi.org/10.1111/j.1744-6570.2011.01211.x

Kyriacou, C. (1987). Teacher stress and burnout: An international review. Educational Research, 29(2), 146-152.

Kyriacou, C., \& Chien, P.-Y. (2004). Teacher stress in Taiwanese primary schools [Online]. The Journal of Educational Enquiry, 5(2).

Lee, K., \& Allen, N. J. (2002). Organizational citizenship behavior and workplace deviance: The role of affect and cognitions. Journal of Applied Psychology, 87(1), 131-142. 
Hu, Y.-L., Hung, C.-H., \& Ching, G. S.

Likert, R. (1932). A technique for the measurement of attitudes. New York: Columbia University Press.

Luthans, F., \& Peterso, S. J. (2002). Employee engagement and manager self-efficacy. Journal of Management Development, 21(5), 376-387. https://doi.org/10.1108/02621710210426864

MacKinnon, D. P., \& Dwyer, J. H. (1993). Estimating mediated effects in prevention studies. Evaluation Review, 17(2), 144-158. https://doi.org/10.1177/0193841X9301700202

MacKinnon, D. P., Lockwood, C. M., Hoffman, J. M., West, S. G., \& Sheets, V. (2002). A comparison of methods to test mediation and other intervening variable effects. Psychological Methods, 7(1), 83-104.

Marcus, B., \& Schuler, H. (2004). Antecedents of counterproductive behavior at work: A general perspective. Journal of Applied Psychology, 89(4), 647-660. https://doi.org/10.1037/0021-9010.89.4.647

Martinko, M. J., Gundlach, M. J., \& Douglas, S. C. (2002). Toward an integrative theory of counterproductive workplace behavior: A causal reasoning perspective. International Journal of Selection and Assessment, 10(1-2), 36-50. https://doi.org/10.1111/1468-2389.00192

Mauno, S., Kinnunen, U., \& Ruokolainen, M. (2007). Job demands and resources as antecedents of work engagement: A longitudinal study. Journal of Vocational Behavior, 70(1), 149-171. https://doi.org/10.1016/j.jvb.2006.09.002

Miles, D. E., Borman, W. E., Spector, P. E., \& Fox, S. (2002). Building an integrative model of extra role work behaviors: A comparison of counterproductive work behavior with organizational citizenship behavior. International Journal of Selection and Assessment, 10(1-2), 51-57. https://doi.org/10.1111/1468-2389.00193

Moorman, R. H., Niehoff, B. P., \& Organ, D. W. (1993). Treating employees fairly and organizational citizenship behavior: Sorting the effects of job satisfaction, organizational commitment, and procedural justice. Employee Responsibilities and Rights Journal, 6(3), 209-225. https://doi.org/10.1007/BF01419445

Moretti, D. M. (1986). The prediction of employee counterproductivity through attitude assessment. Journal of Business and Psychology, 1(2), 134-147.

Motowildo, S. J., Borman, W. C., \& Schmit, M. J. (1997). A theory of individual differences in task and contextual performance. Human Performance, 10(2), 71-83. https://doi.org/10.1207/s15327043hup1002_1

Nguyen, B., Chang, K., Rowley, C., \& Japutra, A. (2016). Organizational citizenship behavior, identification, psychological contract and leadership frames: The example of primary school teachers in Taiwan. Asia-Pacific Journal of Business Administration, 8(3), 260-280. https://doi.org/10.1108/APJBA-01-2016-0010

Nulty, D. D. (2008). The adequacy of response rates to online and paper surveys: what can be done? Assessment \& Evaluation in Higher Education, 33(3), 301-314. https://doi.org/10.1080/02602930701293231

Organ, D. W. (1988). Organizational citizenship behavior: The good soldier syndrome. Lexington, MA, England: Lexington Books.

Organ, D. W. (1997). Organizational citizenship behavior: It's construct clean-up time. Human Performance, 10(2), 85-97. https://doi.org/10.1207/s15327043hup1002_2

Organ, D. W., \& Ryan, K. (1995). A meta-analytic review of attitudinal and dispositional predictors of organizational citizenship behavior. Personnel Psychology, 48(4), 775-802. https://doi.org/10.1111/j.1744-6570.1995.tb01781.x

Penney, L. M., \& Spector, P. E. (2005). Job stress, incivility, and counterproductive work behavior: The moderating role of negative affectivity. Journal of Organizational Behavior, 26, 777-796. https://doi.org/10.1002/job.336

Phillips, M. C., Meek, S. W., \& Vendemia, J. M. C. (2011). Understanding the underlying structure of deceptive behaviors. Personality and Individual Differences, 50(6), 783-789. https://doi.org/10.1016/j.paid.2010.12.031

Podsakoff, P. M., \& MacKenzie, S. B. (1997). Impact of organizational citizenship behavior on organizational performance: A review and suggestion for future research. Human Performance, 10(2), 133-151. https://doi.org/10.1207/s15327043hup1002_5

Podsakoff, P. M., MacKenzie, S. B., Paine, J. B., \& Bachrach, D. G. (2000). Organizational citizenship behaviors: A critical review of the theoretical and empirical literature and suggestions for future research. Journal of Management, 26(3), 513-563. https://doi.org/10.1177/014920630002600307

Rhoades, L., \& Eisenberger, R. (2002). Perceived organizational support: A review of the literature. Journal of Applied Psychology, 87(4), 698-714. https://doi.org/10.1037/0021-9010.87.4.698

Rich, B. L., Lepine, J. A., \& Crawford, E. R. (2010). Job engagement: Antecedents and effects on job performance. Academy of Management Journal, 53(3), 617-635. https://doi.org/10.5465/AMJ.2010.51468988

Robbins, J. M., Ford, M. T., \& Tetrick, L. E. (2012). Perceived unfairness and employee health: A meta-analytic 
Shifting between CWB and OCB: The effects of workplace support and engagement

integration. Journal of Applied Psychology, 92(2), 235-272. https://doi.org/10.1037/a0025408

Roberts, D. R., \& Davenport, T. O. (2002). Job engagement: Why it's important and how to improve It. Employment Relations Today, 29(3), 21-29. https://doi.org/10.1002/ert.10048

Robinson, S. L., \& Bennett, R. J. (1995). A typology of deviant workplace behaviors: A multidimensional scaling study. Academy of Management Journal, 38(2), 555-572.

Sackett, P. R. (2002). The structure of counterproductive work behaviors: Dimensionality and relationships with facets of job performance. International Journal of Selection and Assessment, 10(1-2), 5-11. https://doi.org/10.1111/1468-2389.00189

Sackett, P. R., Berry, C. M., Wiemann, S. A., \& Laczo, R. M. (2006). Citizenship and counterproductive behavior: Clarifying relations between the two domains. Human Performance, 19(4), 441-464. https://doi.org/10.1207/s15327043hup1904_7

Saks, A. M. (2006). Antecedents and consequences of employee engagement. Journal of Managerial Psychology, 21(7), 600-619. https://doi.org/10.1108/02683940610690169

Salanova, M., Agut, S., \& Peiró, J. M. (2005). Linking organizational resources and work engagement to employee performance and customer loyalty: The mediation of service climate. Journal of Applied Psychology, 90(6), 1217-1227. https://doi.org/10.1037/0021-9010.90.6.1217

Sax, L. J., Gilmartin, S. K., \& Bryant, A. N. (2003). Assessing response rates and nonresponse bias in web and paper surveys. Research in Higher Education, 44(4), 409-432. https://doi.org/10.1023/A:1024232915870

Schat, A. C. H., \& Kelloway, E. K. (2003). Reducing the adverse consequences of workplace aggression and violence: The buffering effects of organizational support. Journal of Occupational Health Psychology, $8(2), 110-122$. https://doi.org/10.1037/1076-8998.8.2.110

Schaufeli, W. B., Bakker, A. B., \& Salanova, M. (2006). The measurement of work engagement with a short questionnaire: A cross-national study. Educational and Psychological Measurement, 66(4), 701-716. http://dx,doi,org/10.1177/0013164405282471

Shrout, P. E., \& Bolger, N. (2002). Mediation in experimental and nonexperimental studies: New procedures and recommendations. Psychological Methods, 7(4), 422-445. https://doi.org/10.1037/1082-989X.7.4.422

Smith, C. A., Organ, D. W., \& Near, J. P. (1983). Organizational citizenship behavior: Its nature and antecedents. Journal of Applied Psychology, 68(4), 653-663. https://doi.org/10.1037/0021-9010.68.4.653

Sobel, M. E. (1982). Asymptotic intervals for indirect effects in structural equations models. In S. Leinhart (Ed.), Sociological methodology 1982 (pp. 290-312). San Francisco, CA: Jossey-Bass.

Somech, A., \& Bogler, R. (2002). Antecedents and consequences of teacher organizational and professional commitment. Educational Administration Quarterly, 38(4), 555-577. https://doi.org/10.1177/001316102237672

Spector, P. E. (1987). Method variance as an artifact in self-reported affect and perceptions at work: Myth or significant problem? Journal of Applied Psychology, 72(3), 438-443. https://doi.org/10.1037/0021-9010.72.3.438

Spector, P. E. (2006). Method variance in organizational research: Truth or urban legend? Organizational Research Methods, 9(2), 221-232. https://doi.org/10.1177/1094428105284955

Spector, P. E. (2011). The relationship of personality to counterproductive work behavior (CWB): An integration of perspectives. Human Resource Management Review, 21(4), 342-352. https://doi.org/10.1016/j.hrmr.2010.10.002

Spector, P. E., \& Fox, S. (2010). Counterproductive work behavior and organisational citizenship behavior: Are they opposite forms of active behavior? Applied Psychology, 59(1), 21-39. https://doi.org/10.1111/j.1464-0597.2009.00414.x

Spector, P. E., Fox, S., Penney, L. M., Bruursema, K., Goh, A., \& Kessler, S. (2006). The dimensionality of counterproductivity: Are all counterproductive behaviors created equal? Journal of Vocational Behavior, 68(3), 446-460. https://doi.org/10.1016/j.jvb.2005.10.005

Stone, C. A., \& Sobel, M. E. (1990). The robustness of estimates of total indirect effects in covariance structure models estimated by maximum. Psychometrika, 55(2), 337-352. https://doi.org/10.1007/BF02295291

Stone, T. H., \& Jawahar, I. M. (2015). Career implications of job performance: Persistence of OCB and CWB behaviors across domains. In A. De Vos \& B. I. J. M. Van der Heijden (Eds.), Handbook of research on sustainable careers (pp. 398-414). Cheltenham, UK: Edward Elgar.

Tucker, L. R., \& Lewis, C. (1973). A reliability coefficient for maximum likelihood factor analysis. Psychometrika, 38(1), 1-10. https://doi.org/10.1007/BF02291170

Vagg, P. R., \& Spielberger, C. D. (1998). Occupational stress: Measuring job pressure and organizational support in the workplace. Journal of Occupational Health Psychology, 3(4), 294-305. https://doi.org/10.1037/1076-8998.3.4.294 
Hu, Y.-L., Hung, C.-H., \& Ching, G. S.

Valli, L., \& Buese, D. (2007). The changing roles of teachers in an era of high-stakes accountability. American Educational Research Journal, 44(3), 519-558. http://dx,doi.org/10.3102/0002831207306859

Van Scotter, J. R., \& Motowidlo, S. J. (1996). Interpersonal facilitation and job dedication as separate facets of contextual performance. Journal of Applied Psychology, 81(5), 525-531. https://doi.org/10.1037/0021-9010.81.5.525

Warr, P., \& Inceoglu, I. (2012). Job engagement, job satisfaction, and contrasting associations with person-job fit. Journal of Occupational Health Psychology, 17(2), 129-138. https://doi.org/10.1037/a0026859

Wefald, A. J., \& Downey, R. G. (2009). Job engagement in organizations: Fad, fashion, or folderol? Journal of Organizational Behavior, 30(1), 141-145.

Yoon, J., \& Lim, J.-C. (1999). Organizational support in the workplace: The case of Korean hospital employees. Human Relations, 52(7), 923-945. https://doi.org/10.1177/001872679905200704

Zhong, L., Wayne, S. J., \& Liden, R. C. (2015). Job engagement, perceived organizational support, high-performance human resource practices, and cultural value orientations: A cross-level investigation. Journal of Organizational Behavior, 37, 823-844. https://doi.org/10.1002/job.2076 